\title{
ULTRA STRUCTURAL DELETERIOUS IN THE COTTON LEAF WORM, Spodoptera littoralis (BOISD.) LARVAE TREATED WITH CERTAIN INSECTICIDES
}

\author{
Nancy N. Hassan ${ }^{1}$; H.E. El-Metwally ${ }^{1}$; Dalia A. Barakat ${ }^{1}$; E.E. Attia ${ }^{2}$ and \\ R.A.M. Amer ${ }^{3}$ \\ 1- Depart. of Econ. Entomol. \& Pesticide, Faculty of Agriculture, Cairo University, Giza, \\ Egypt. \\ 2- Depart. of Entomol., Faculty of Science, Ain Shams University, Cairo, Egypt. \\ 3- Plant Protection Research Institute, Agriculture Research Center, Giza, Egypt.
}

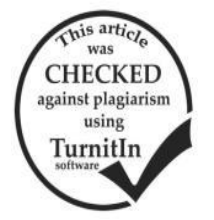

ABSTRACT

\begin{abstract}
Cypermethrin, esfenvalerate, chlorpyrifos and Bacillus thuringiensis, Kurs. were tested against the cotton leaf worm, Spodoptera littoralis (Boisd.) treated as $4^{\text {th }}$ instar larvae. In addition, $\mathrm{LC}_{50}$ 's of tested compounds were applied on $S$. littoralis larvae to investigate the ultra structural changes in the integument, muscle, fat body and mid gut of alive and dead larvae. Meanwhile, the nerve cord sections were investigated for alive larvae only. All investigations were done by light and electronic microscopes.

Cypermethrin was the most potent compounds against $S$. littoralis larvae, followed by esfenvalerate, chlorpyrifos and then $B$. thuringiensis that had the least toxicity on the cotton leaf worm compared to other tested compounds.

Ultra structural investigations showed that cypermethrin caused thickening of outer cuticle fibrous layer in the integument of S. littoralis larvae. Also, hypodermis layer had swelling at the same treatment and necrosis in other treatments. In addition, all the treatments caused appearance of fissure and breaking down of muscles into small parts. While, all tested compounds except B. thuringiensis caused swelling in the integuments of dead larvae compared to control. On the other hand, B. thuringiensis caused drastically necrosis in the integument and hypodermis layers of dead larvae. All the compounds caused a noticeable destruction on the fat body cells as well as vacuolization and destruction the fat body membranous sheath. Many deleterious effects in the mid gut of $S$. littoralis as destruction of columnar or hyperphesia cells lining mid gut, losses of brush border with increase of goblet cells. Mid gut of died larvae had the highly destruction as affected by cypermethrin treatment. Meanwhile, other treatments caused shrinking in mid gut parts and necrosis in another parts. Neurosecretory cells of $S$. littoralis larval nerve cord had shrunk and dwarfed in cypermethrin, chlorpyrifos and B. thuringiensis, while; it had swelling in esfenvalerate treatment. Also, nucleus and nerve cells were disappeared partly in the most treatment compared to control.
\end{abstract}

Keywords: $S$. littoralis, toxicity, ultra structural, integument, muscle, fat body, mid gut, nerve cord, cypermethrin, esfenvalerate, chlorpyrifos, B. thuringiensis.

\section{INTRODUCTION}

Cotton leaf worm, Spodoptera littoralis (Boisd.), is a major cotton pest having a high reproductive capacity that averages 1000 eggs/female. In Egypt, It has three generations during cotton season (Abul-Nasr and El-Sherif; 1973) and is considered a limiting factor affecting crop and vegetable production. Despite of using insecticides eventually created many problems as resistance, and adverse effects on non-target organisms, but insecticides still represent a secure valve in controlling most of pests, among the Integrated Pest Management Programs. The bacterium Bacillus thuringiensis, proved to be a highly successful weapon for fighting some agricultural pests and offering many advantages over chemical insecticides. Using such agent as a microbial bio-insecticide increased during the past decade (Dulmage and Co-operators, 1981). AbdElwahed, et al. (2011) stated the potency of $B$. thuringiensis var. kurstaki against $S$. littoralis treated as $4^{\text {th }}$ instar larvae with $\mathrm{LC}_{50}$ of tested compound caused aberrations in the mid gut layers. Also, El-Sheikh (2012) evaluated the insecticidal and histological effects of diple-2X (B. thuringiensis) and one pyrethroid compound (cypermethrin) on $4^{\text {th }}$ instar larvae of $S$. littoralis based on the $\mathrm{LC}_{50}$ values cypermethrin is more toxic to S. littoralis than other compound, different abnormal histological structures of ovary were noticed. Osman and Abou-zeid (2015) conducted that organophosphorus insecticide, Profenofos (selecron) was sprayed on cotton leaves for controlling $4^{\text {th }}$ instar larvae of cotton leaf worm under semi field circumstances, follow up histological changes happened in destruction of cell walls body, mid gut and cuticle layers of treated insect.

Thus, the purpose of the current work was to study the effect of cypermethrin (synthetic pyrethroid), esfenvalerate (synthetic pyrethroids), chlorpyrifos (organophosphorus) and B. thuringiensis on the cotton leaf worm, $S$. littoralis treated as $4^{\text {th }}$ instars larvae with $\mathrm{LC}_{50}$ 's of the mentioned compounds to be investigating the ultra structural of the larval integument, muscle, fat body and mid gut tissues of alive and dead larvae. Also, nerve cord section of $S$. littoralis for alive larvae was examined by using light and electronic microscopes.

\section{MATERIALS AND METHODS}

\section{Insect Rearing.}

The culture of the cotton Leaf worm, S. littoralis was maintained in the laboratory of Cotton Leaf Worm Department, Plant Protection Research Institute, Agriculture Research Center. Larvae were fed on fresh castor oil plant leaves, Ricinus communies under laboratory conditions of $27 \pm 2{ }^{\circ} \mathrm{C}$ and $65 \%$ R.H. (ElDefrawi et al. (1964).

2. Tested compounds.

a. Synthetic pyrethroid compounds

1. Esfenvalerate; (Sumi-alpha, $5 \% \mathrm{EC}$ )

IUPAC Name: $(S)$ - $\alpha$-cyano-3-henoxybenzyl $(S)$-2-(4- 3 -cloro- phenyl) methylbutyrate. The rate dose is 400 
ml/faddan. It is the product of Kafr El-Ziat for Pesticide and Chemicals Company.<smiles>CC(C)[C@H](C)OC(=O)[C@H](C)c1cccc(Oc2ccccc2)c1</smiles>

2.Cypermethrin: (Sparkel, 25\% EC)

IUPAC Name: (RS)- $\alpha$-cyano-3 phenoxybenzyl-(1RS)cis,trans-3-(2,2-dichlorovinyl)-2,2-dimethylcyclopropane carboxylate (4 isomer pairs: cis- 1 , cis- 2 , trans-3, trans-4). It used at rate dose of $250 \mathrm{ml} /$ faddan. It is the product of ElHelb for Pesticide and Chemicals Company.

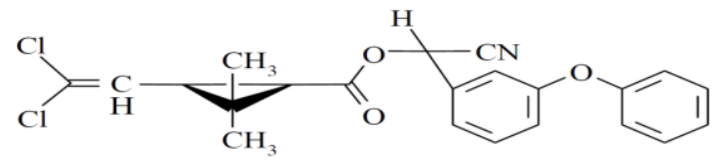

b. Organophosphorus compound

1.Chlorpyrifos: (Dursban, $\mathbf{4 8 \%}$ EC)

IUPAC Name: O, O-diethyl O - 3, 5, 6-trichloro -2pyridyl phosphorothioate. The rate dose is $1 \mathrm{~L} /$ faddan. It is the product of National Company for Agriculture Chemicals Production.<smiles>CCO[PH](=S)Oc1nc(Cl)c(Cl)cc1Cl</smiles>

\section{c. Biopesticides}

\section{Dipel 2X: 6.4\%WP}

Dipel $2 \mathrm{X}$ is one of the commercial microbial products in which the active ingredient based on the bacterium, Bacillius. thuringiensis var. kurstaki, a product of Vailent Bioscience Corporation, USA was obtained from May trade company, Giza, Egypt, containing 32.000 international unites potency per $\mathrm{mg}$ (IU $/ \mathrm{mg}$ ). It was used as wettable powder and at recommended at rate $200 \mathrm{gm} /$ faddan.

\section{Toxicity of tested compounds on $S$. littoralis larvae.}

Dipping technique was used at the present work. The castor oil leaves dipping in five tested compound concentrations of cypermethrin, esfenvalerate, chlorpyrifos and B. thuringiensis (Dipel 2X). Four replicates for each concentration of the tested compound for $20 \mathrm{sec}$. and left the castor leaves until water evaporated, then put in glass jars $(11 \times 22 \mathrm{~cm})$. Each jar was prepared by 25 fourth instar larvae of cotton leaf worm after larvae starving about 4 hours and maintained under $26 \pm 1{ }^{\circ} \mathrm{C}$. Then the numbers of alive and dead larvae were counted two days after treatment.

$\mathrm{LC}_{50}$ values were assessed according to Finney (1971) by using Ldp line software (www.Ehabbakr software/Ldp line).

\section{Light microscope.}

Fourth instars larvae of $S$. littoralis treated with $\mathrm{LC}_{50}$ 's of the tested compounds (cypermethrin, esfenvalerate, chlorpyrifos and $B$. thuringiensis). Larvae at 6- day after treatment were maintained in formalin $10 \%$ until histology.
The specimens from $S$. littoralis larvae samples were collected and fixed in $10 \%$ buffered neutral formalin solution. Paraffin sections of 5 microns thickness were prepared and stained with haematoxylin and eosin (H \& E) according to Bancroft, et al. (1990) and examined microscopically. The alive and dead larval integument, muscle and fat bodies were investigated microscopically (X 200), While, mid gut (x 400).

All sections of $S$. littoralis larvae were done at Animal Health Research Institute, Agriculture Research Center.

Alive larval nerve cord sections were done at Cairo University Research Park (CURP) as the method of Bozzola and Russell (1999). Slice tissue was processed for TEM by fixation in glutaraldehyde and osmium tetroxide, dehydrated in alcohol and embedded in an epoxy resin. Microtome sections prepared at approximately 500-1000 $\mu \mathrm{m}$ thickness with a Leica Ultracut UCT ultra microtome. Thin sections were stained with tolodin blue (1X) then sections were examined by camera Lica ICC50 HD.

\section{Electronic microscope.}

The work was done in TEM lab FA-CURP, Fac. of Agric., Cairo University Research Park by using method of Bozzola and Russell (1999). Slice tissue samples into $\sim 1 \mathrm{~mm}$ slices. Slice tissue was processed for TEM by fixation in glutaraldehyde and osmium tetroxide, dehydrated in alcohol and embedded in an epoxy resin. Microtome sections prepared at approximately 75-90 $\mu \mathrm{m}$ thickness and were stained with uranyl acetate and lead citrate, then examined by transmission electronic microscope JEOL (JEM-1400 TEM) at the candidate magnification. Images were captured by CCD camera model AMT, optronics camera with 1632 x 1632 pixel format as side amount configuration. This camera uses a 1394 fire wire board for acquision. The alive larval integument, muscle, fat body and nerve cord were investigated by electronic microscope.

\section{RESULTS AND DISCUSSION}

\section{Efficacy of the tested compounds on S. littoralis.}

The cotton leaf worm, S. littoralis treated as $4^{\text {th }}$ instar larvae by synthetic pyrethroid compounds of cypermethrin and esfenvalerate; also, organophosphorus compound (chlorpyrifos) and Bactericide (B. thuringiensis). Table (1) showed that cypermethrin was the most potent compound against $S$. littoralis larvae $\left(\mathrm{LC}_{50}: 0.0387 \mathrm{ppm}\right)$, followed by esfenvalerate $(0.2546$ ppm), chlorpyrifos (1.0884 ppm) and B. thuringiensis (7.7523 ppm) after 3- day from treatment.

El- Sheikh (2012) evaluated Diple 2x (B. thuringiensis) and cypermethrin on S. littoralis $4^{\text {th }}$ instar larvae. Based on the $\mathrm{LC}_{50}$ values; cypermethrin is the more toxic to $S$. littoralis than another compound. Also, Bhatti, et al. (2013) presently two pyrethroids and three new chemistry insecticides in mixtures at their lethal concentrations against $2^{\text {nd }}$ instar larvae of Spodoptera litura. $\mathrm{LC}_{50}$ of deltamethrin and bifenthrin were 619 \& 100 and $0.06 \& 73.4 \mathrm{ul} / \mathrm{ml}$, respectively after 48 and 72 hour exposure. In addition, Massoud, et al. (2014) and 
Osman (2014) showed that chlorpyrifos-methyl was effective against cotton leafworm. Moreover, Ibrahim, et al. (2014) indicated that mortality percentage increased with increasing Dipel $2 \mathrm{X}$ concentration. The highest mortality (90\%) was obtained by using $4 \mathrm{~g} / \mathrm{L}$ of Dipel 2X (5 days post treatment).

Table (1). Toxicity of tested compounds on 4th instar larvae of S. littoralis.

\begin{tabular}{|c|c|c|c|c|c|}
\hline \multirow[t]{2}{*}{ Compounds } & \multirow{2}{*}{$\begin{array}{c}\mathrm{LC}_{50}(\mathrm{ppm}) \\
95 \% \text { Confidence limits }\end{array}$} & \multirow{2}{*}{$\begin{array}{c}\mathbf{L C}_{90}(\mathbf{p p m}) \\
95 \% \text { Confidence limits }\end{array}$} & \multirow{2}{*}{$\begin{array}{l}\text { Slope } \pm \\
\text { SE }\end{array}$} & \multicolumn{2}{|c|}{$\begin{array}{c}\text { Toxicity } \\
\text { index }\end{array}$} \\
\hline & & & & $\mathrm{LC}_{\mathbf{5 0}}$ & $\mathrm{LC}_{90}$ \\
\hline Cypermethrin & $\begin{array}{c}0.0387 \\
0.0261 \pm 0.0568\end{array}$ & $\begin{array}{c}0.8082 \\
0.4331 \pm 1.993\end{array}$ & $\begin{array}{c}0.9708 \pm \\
0.1050\end{array}$ & 100 & 100 \\
\hline Esfenvalerate & $\begin{array}{c}0.2546 \\
0.163 \pm 0.3964\end{array}$ & $\begin{array}{c}9.0785 \\
4.1673 \pm 29.841\end{array}$ & $\begin{array}{c}0.8257 \pm \\
0.0986\end{array}$ & 15.20 & 8.90 \\
\hline Chlorpyrifos & $\begin{array}{c}1.0884 \\
0.7212 \pm 1.6965\end{array}$ & $\begin{array}{c}26.817 \\
12.318 \pm 91.543\end{array}$ & $\begin{array}{c}0.9209 \pm \\
0.1162\end{array}$ & 3.55 & 3.01 \\
\hline $\begin{array}{l}\text { B. thuringiensis } \\
\text { (IU/L) }\end{array}$ & $\begin{array}{c}7.7523 \\
5.1557 \pm 12.456\left(24 \times 10^{6}\right) \\
\left(16 \times 10^{6} \pm 39 \times 10^{6}\right)\end{array}$ & $\begin{array}{c}195.91 \\
88.054 \pm 660.65\left(6 \times 10^{8}\right) \\
\left(2.8 \times 10^{8} \pm 21 \times 10^{8}\right)\end{array}$ & $\begin{array}{c}0.9137 \pm \\
0.1056\end{array}$ & 0.49 & 0.41 \\
\hline
\end{tabular}

\section{Ultra structural studies.}

\section{A. Integuments.}

Normal cuticle of $S$. littoralis larvae composed of an outermost distinct layer, the epicuticle and the inner layer called procuticle. Procuticle parts are hardened to form the exocuticle; while, other parts remain flexible and colorless to form endocuticle. Finally there is commonly a distinct layer called hypodermal layer which composed of columnar or cuboidal cells (Figs. 1\&2). Ultra structural examinations of $S$. littoralis 6th instar larvae treated as 4th instar larvae with LC50 of cypermethrin revealed a swelling and separation of the hypodermal cells from the endocuticle and the hypodermal cells showed several mitotic divisions and some fissure. Distortion in the endocuticle was also quite visible. This distortion revealed blockage of its formation. Es-fenvalerate caused abnormalities in the shape of exocuticle and hypodermal cells separated from the endocuticle (Figs. 1\&2). As shown in (Figs. 1\&2) the thickness of the cuticle decreased, some hypodermal cells became separated from the endocuticle. These results accorded with the demonstrated by El-Sheikh et al. (2005). Meanwhile, other tested compounds caused slurping from hypodermis layer. All the compounds caused elicited a lack of differentiation between outer cuticle and endo cuticle, destruction of the basement membrane and appearance of vacuoles between cuticle and hypodermis in the most treatments. Sampsont and Gooday (1998) mentioned that B. thuringiensis subsp. israelensis and subsp. Aizawai secreted exochitinase activity when grown in a medium containing chitin. The involvement of these chitinolytic activities during pathogenesis in insects has been investigated against larvae of S. littoralis.

\section{B. Muscles.}

The larval muscles are composed of striated fibers. Each fiber consists of parallel fibrillate numbers or sacrostyles, occupying the whole cross section of the fiber and laid down in plasma or sacroplasm. The nuclei of the sacroplasm are disposed immediately beneath the sarcolemma. All the treatments had appearance of fissure and breaking down of muscles into small parts are attributed to the destruction of the sarcolemma (Figs.1\&2).

\section{Fat bodies.}

Ultra structural of the normal fat bodies of larvae indicated that they are composed of two layers. An outer or partial layer formed of ribbons beneath the body wall and an inner or visceral layer surrounding the various organs. The ribbon consists of many irregular cells. Their cells surrounded by sheath (Figs.1\&2). The histological changes by different treatments used, showed a noticeable destruction on the fat body cells, as vacuolization of fat cells and destruction of membranous sheath (Figs. 1\&2).

All the treatments had drastically destructions in integument, hypodermal layer; muscle and fat bodies of died larvae. Cypermethrin, esfenvalerate and chlorpyrifos caused noticeable swelling and necrosis; meanwhile, $B$. thuringiensis caused clearly shrinking and destruction in the most investigated tissues compared to normal dead larvae as showed in Fig. (3). El-Metwally, et al. (2007) evaluated the histopathological effects of four compounds; fenpropathrin, diflubenzuron, methomyl and Deenate on the larval integument of Pectinophora gossypiella (Saund.) and Earias insulana (Boisd.) treated as 10- day old larvae. The tested compounds destroyed the larval integument of the treated larvae in both insects. Also, separation between epidermal and hypodemal layers, reduction in the epidermal layer and reduction in muscles were shown by these compounds in addition to duplex structure between old and new cuticle of the spiny bollworm. Also, Osman and Abou-Zaid (2015) found that destruction of some cells in mid gut and cuticle layers of $S$. littoralis that treated with Profenofos. Amer, et al. (2015) mentioned that B. thuringiensis caused thickening of outer cuticle fibrous layer in the integument of $S$. littoralis larvae. Also, hypodermis layer had swelling and necrosis in S. littoralis larvae. Also, it caused appearance of fissure and breaking down of muscles into small parts and noticeable destruction on the fat body cells as vacuolization and destruction of the fat body membranous sheath. 


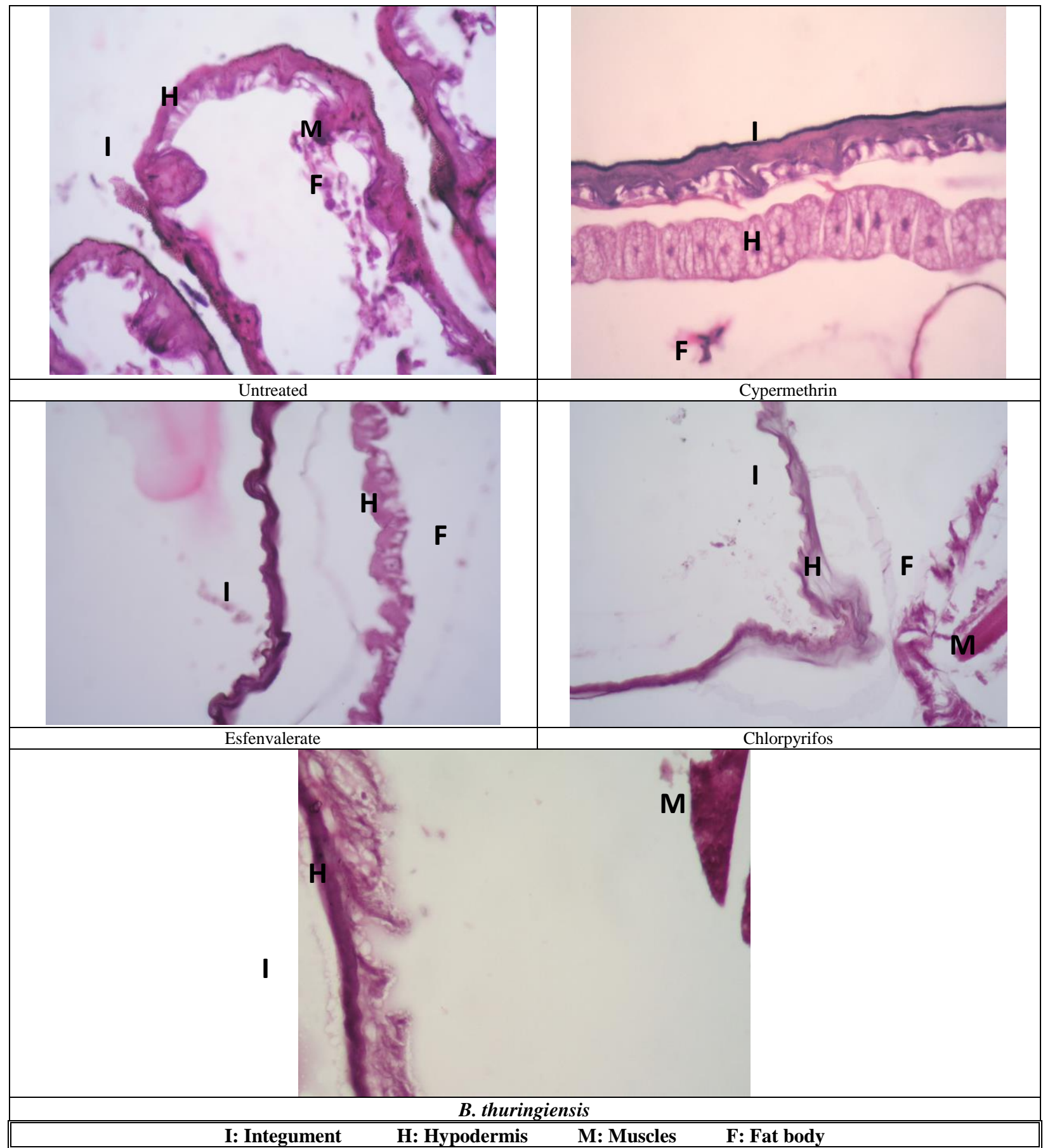

\section{Figure (1): Longitudinal sections by light microscope in alive larval cuticle of $S$. littoralis treated as $4^{\text {th }}$ instar} larvae by tested compounds (X 200).

\section{Mid guts:}

Normal mid gut of $S$. littoralis is the main site for digestion and absorption of the digestion products and is a very metabolically active tissue. It consists of single layer of epithelium placed on a basement membrane. The epithelium is made up of columnar cells, secretory cells. These epithelial cells are relatively high; also, form a regular and compact wall. An oval nucleus is located in the central part of each columnar cell.

The apical surface of each columnar cell bordering with the gut lumen is covered with microvillae which create the tight structure called the brush border. The regenerative cells are another type of cells within the epithelium. These tiny cells from the regenerative cells that is regularly located at the base of the columnar cells (Figs. 4\&5). Goblet cells are interspersed among the columnar cells. The cytoplasm of these pear-shaped cells is reduced, and the apical border of the cell surface invigilates to form a deep cavity. In this cavity there are numerous cytoplasm extensions. Flat nucleus of the goblet cell is located basally, below its cavity. The epithelium rests on welldeveloped basement membrane that is surrounded by a layer of circular muscles and an outer longitudinal muscle coat. 


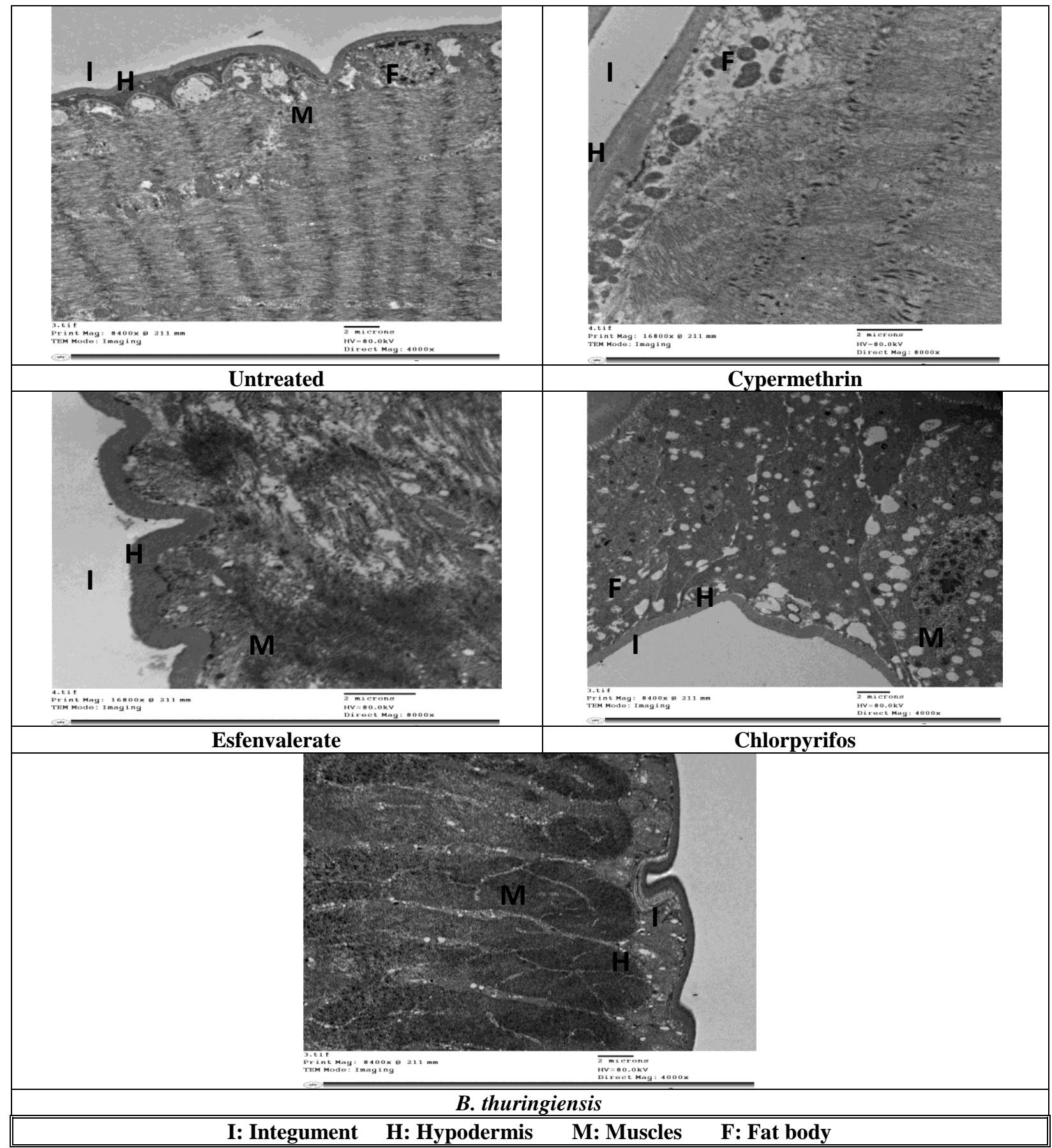

Figure (2): Longitudinal sections by electronic microscope in alive larval cuticle of $S$. littoralis treated as $4^{\text {th }}$ instar larvae by tested compounds (X 4000).

The columnar, goblet and regenerative cells were dwarfing and shrinking noticeable, especially in esfenvalerate treatment, followed by chlorpyrifos and cypermethrin. While, had remarkable damage in all cells of mid gut was happened as a result of $B$. thuringiensis treatment as in Figs. (4\&5). In addition, all tested compounds caused many deleterious effects in the mid gut of S. littoralis larvae as losses of brush border and epithelial cells that were vacuolated. Their nuclei were distinctly enlarged. Brush border was seen on a large surface of epithelial cells, but it disappeared on the most affected cells. Cytoplasm extensions of the goblet cells were degenerated and their fragments were often noted in the cavity of goblet cells. All regenerative cells were lost and the regular structure of the epithelium was disturbed (Figs. 4\&5). Undifferentiated cells of the mid gut formed the regenerative cells of $S$. littoralis larvae that were most sensitive to tested compounds used. Damage to them resulted in the total disruption of the epithelium by preventing the replacement of the secretory cells exhausted by secretory activity. Degree of damage to the regenerative cells seems to be dependent on tested 
Nancy N. Hassan et al.

compound (Figs. 4\&5). The mid gut of dead larvae had noticeable necrosis among cells of columnar, goblet and regenerative cells. Also, destruction was happened

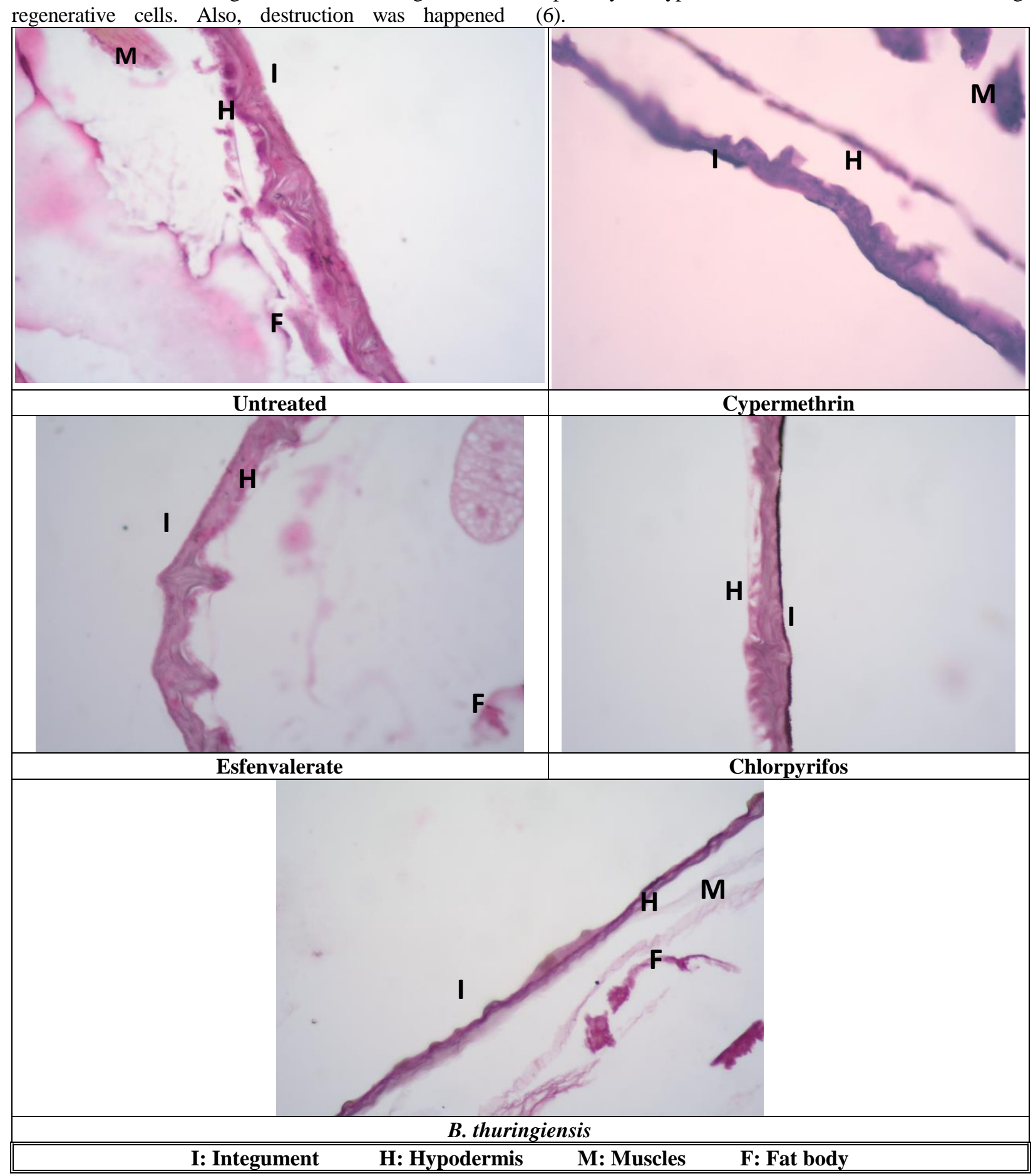

Figure (3): Longitudinal sections by light microscope in dead larval cuticle of $S$. littoralis treated as $4^{\text {th }}$ instar larvae by tested compounds (X 200). between longitudal muscle layer and columnar cells, especially in cypermethrin treatment as showed in Fig. (6). 


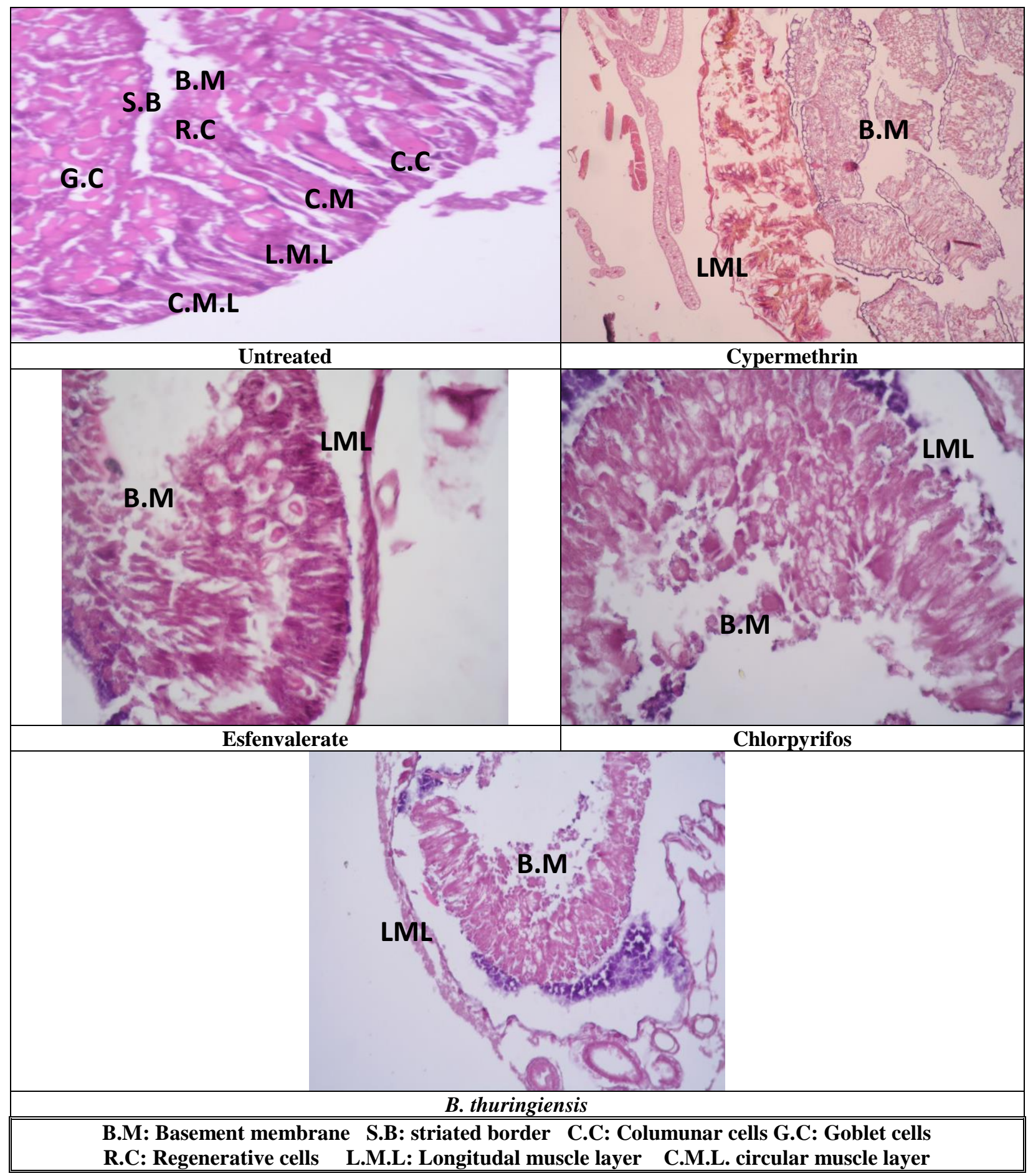

Figure (4): Longitudinal sections by light microscope in alive larval mid gut of $S . \quad$ littoralis treated as $4^{\text {th }}$ instar larvae by tested compounds (X 400). 
Nancy N. Hassan et al.

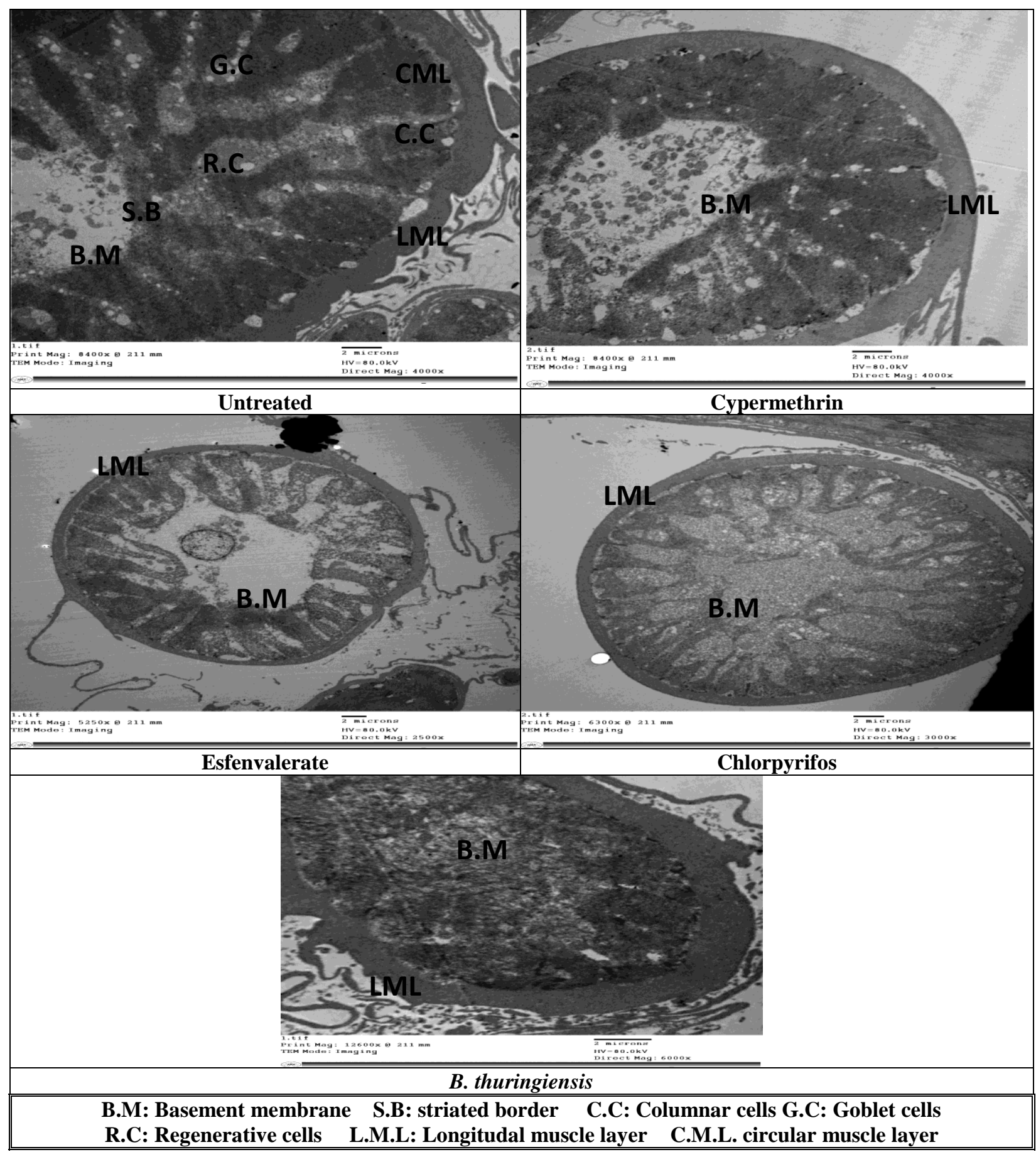

Figure (5): Longitudinal sections by electronic microscope in alive larval mid gut of $S$. littoralis treated as $4^{\text {th }}$ instar larvae by tested compounds (X 4000). 


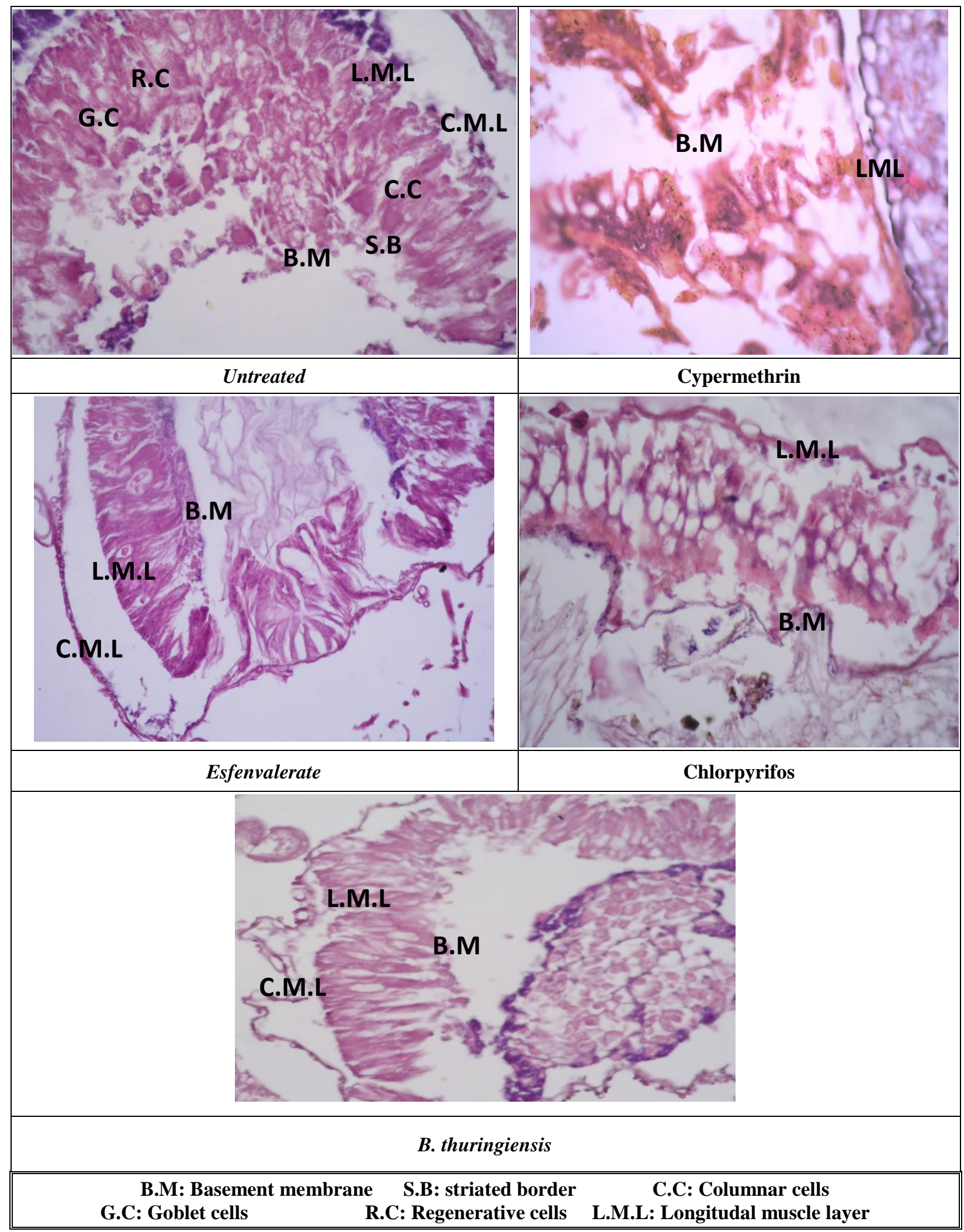

Figure (6): Longitudinal sections by light microscope in dead larval mid gut of $S$. littoralis treated as $4^{\text {th }}$ instar larvae by tested compounds (X 400). 
Similar results were gained by Abd-El Wahed, et al. (2011) who stated the mid gut histological sections of $S$. littoralis $6^{\text {th }}$ instar larvae treated as $4^{\text {th }}$ instar with $\mathrm{LC}_{50}$ of protecto, B. thuringiensis had aberrations in the mid gut layers. Also, Abd El-Mohsen, et al. (2013) showed the effect of $B$. thuringiensis on $2^{\text {nd }}$ and $4^{\text {th }}$ instar larvae of PBW. These effects are completed destruction of mid gut compared with untreated larvae. In addition, Osman and Abou-Zaid (2015) found that destruction of $S$. littoralis mid gut treated with profenofos. Moreover, Amer, et al. (2015) showed that B. thuringiensis caused many deleterious effects in the mid gut of $S$. littoralis as destruction of columnar or hyperphesia cells lining mid gut, losses of brush border with increase of goblet cells.

\section{E- Nerve cord section.}

The whole nerve cord of untreated S. littoralis larvae is limited by a syncytial sheath (Figs.7\&8). Neurosecretory (NSCs) and nerve cells (NCs) of nerve cord are localized in the cortical as well as in the internal regions of the nerve cord (Figs.7\&8). The NSCs showed different shapes and intensities of the neurosecretory material (NSM). At the anterior portion of the nerve cord, there was a cluster of round cells with round nuclei having plenty of chromatin. Some of these cells have prominent nucleoli at their nuclear membrane. Others have small round nucleus having scanty chromatin. The cytoplasm (CY) of all these cells appeared devoid of neurosecretory granules. On the other hand, the posterior portion of nerve cord exhibited different shapes of NSCs (round, irregular, triangle and oval). The neurosecretory granules (NSG) of all the previously mentioned cells were distributed in the entire perikarya of the cells and in triangle-shaped cells; they could be traced up to certain distance in the axon. These NSCs could be considered in the synthesis phase of cell activity according to Tripathi and Arif (2005) who observed four phases of cell activity in Indian silk worm, Antheraea mylitta, including synthesis, coalescence, release and resting phases. The synthesis phase is characterized by synthesis of neurosecretory granules that were scattered in the entire perikaryon. Also, the nerve cord section had yolk cells (Y.C) and neural groove (N.G) that has plenty cytoplasm as showed in figs. (7\&8).

Hamouda and Dahi (2008) evaluated the neurotoxic effect of spinetoram on S. littoralis larvae. Spinetoram is neurotoxicity was manifested as evident histopathological changes in the structure of neurosecretory (NSCs) and ordinary nerve cells (NCs) of suboesophageal ganglion (SOG) of this pest after treatment with $\mathrm{LC}_{50}$ of this compound. It showed aggregation of neurosecretory granules in the oval, triangle and irregular shaped neurosecretory cells but not in the round shaped cells. Also, the SOG of treated larvae showed an apparent vacuolization and increase in the size of cytoplasm, abundance and aggregation of mitochondria in nerve cells and all kinds of NSCs (round, irregular, triangle and oval).

Generally, toxicity and ultra-structural studies cleared that tested compound of cypermethrin, esfenvalerate, chlorpyrifos and $B$. thuringiensis had destructive effects on alive and dead larvae of $S$. littoralis in integument, muscle, fat body and mid gut treated as $4^{\text {th }}$ instars larvae compared to control. Also, cypermethrin is considered the best efficient compound, followed by esfenvalerate, chlorpyrifos and $B$. thuringiensis. Meanwhile, chlorpyrifos was the most neurotoxicity agent than other tested compounds.

In the present study, chlorpyrifos was the most compound had impact factors on the nerve cord, it caused shrinking in the nerve cord section; in addition, the same compound caused necrosis in neuro plasts, neurosecretory cells, nuleus and yolk cells as showed in Figs. (7\&8). The different neurosecretory cells had clustered; also, necrosis in the most of nucleus, yolk cells and syncytial sheath as affected by cypermethrin treatment. Esfenvalerate had necrosis in neuro plasts and most of nerve cord content (Fig. 7,8). Meanwhile, B. thuringiensis had swelling in syncytial sheath and necrosis in both neuro plasts and neuleus (Figs. $7 \& 8$ ). According to Tripathi and Arif (2005) the NSCs in the treated S.littoralis larvae could be considered in synthesis phase of cell activity, while oval, irregular and triangle shaped cells were in releasing phase or in coinciding synthesis and releasing phases. These findings suggested that production of NSG might have been going on at higher rate than their release from most shapes of NSCs in S.littoralis larvae treated with $\mathrm{LC}_{50}$ of cypermethrin, esfenvalerate and chlorpyrifos might have interfered with normal release of NSG leading to their accumulation in oval, triangle and irregular shaped neurosecretory cells (Figs. 7\&8). However, the scarcity of the NSGs in the round NSCs of the untreated and treated larvae may suggest slow production and / or high rate of NSG release than in other shapes of NSCs. Moreover; multivesicular bodies were observed in the cytoplasm of the NSCs of nerve cord the treated larvae, especially in B. thuringiensis in the present study. 


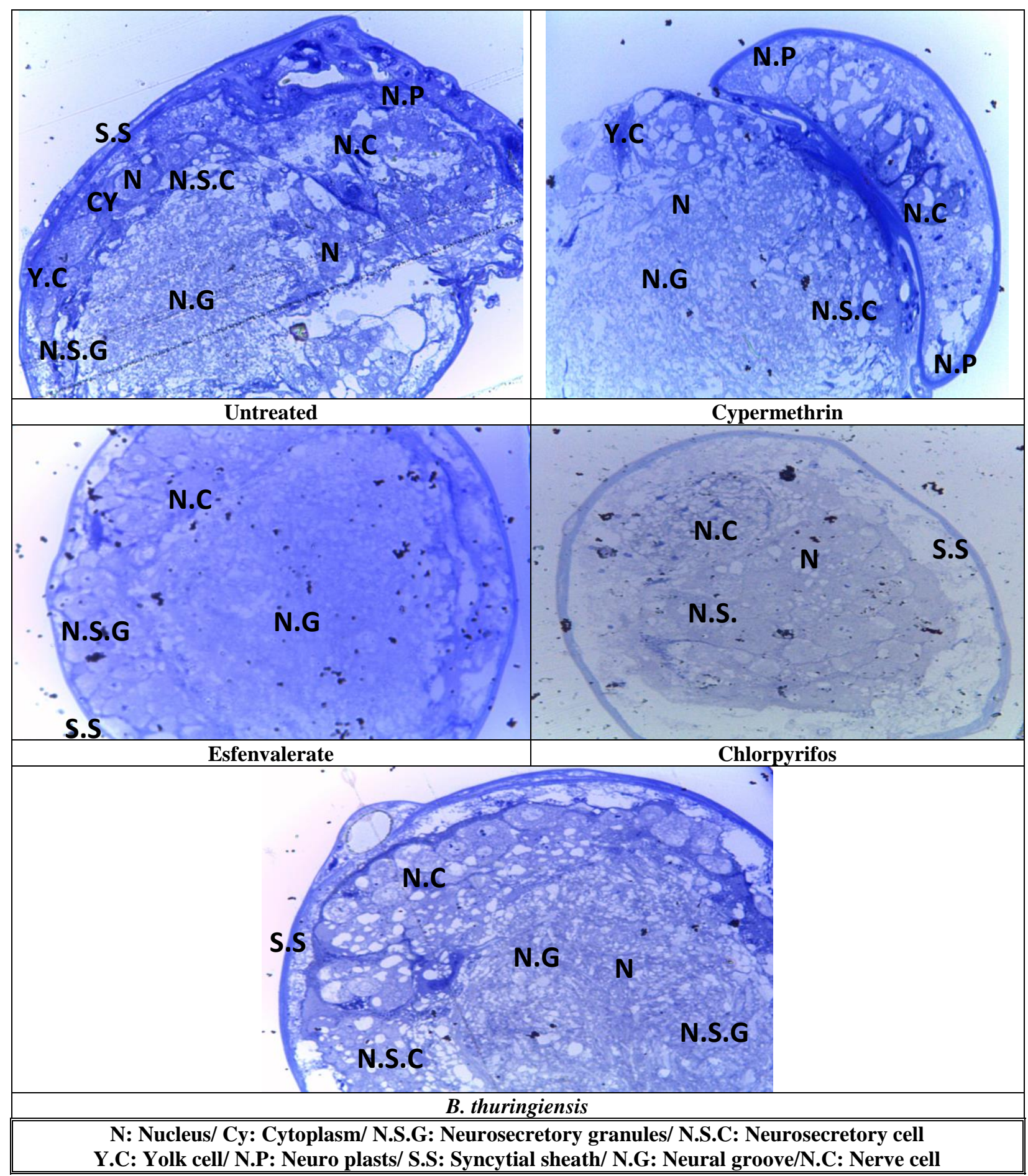

Figure (7): Longitudinal sections by light microscope in nerve cord of $S$. littoralis treated as $4^{\text {th }}$ instar larvae by tested compounds (X 400). 


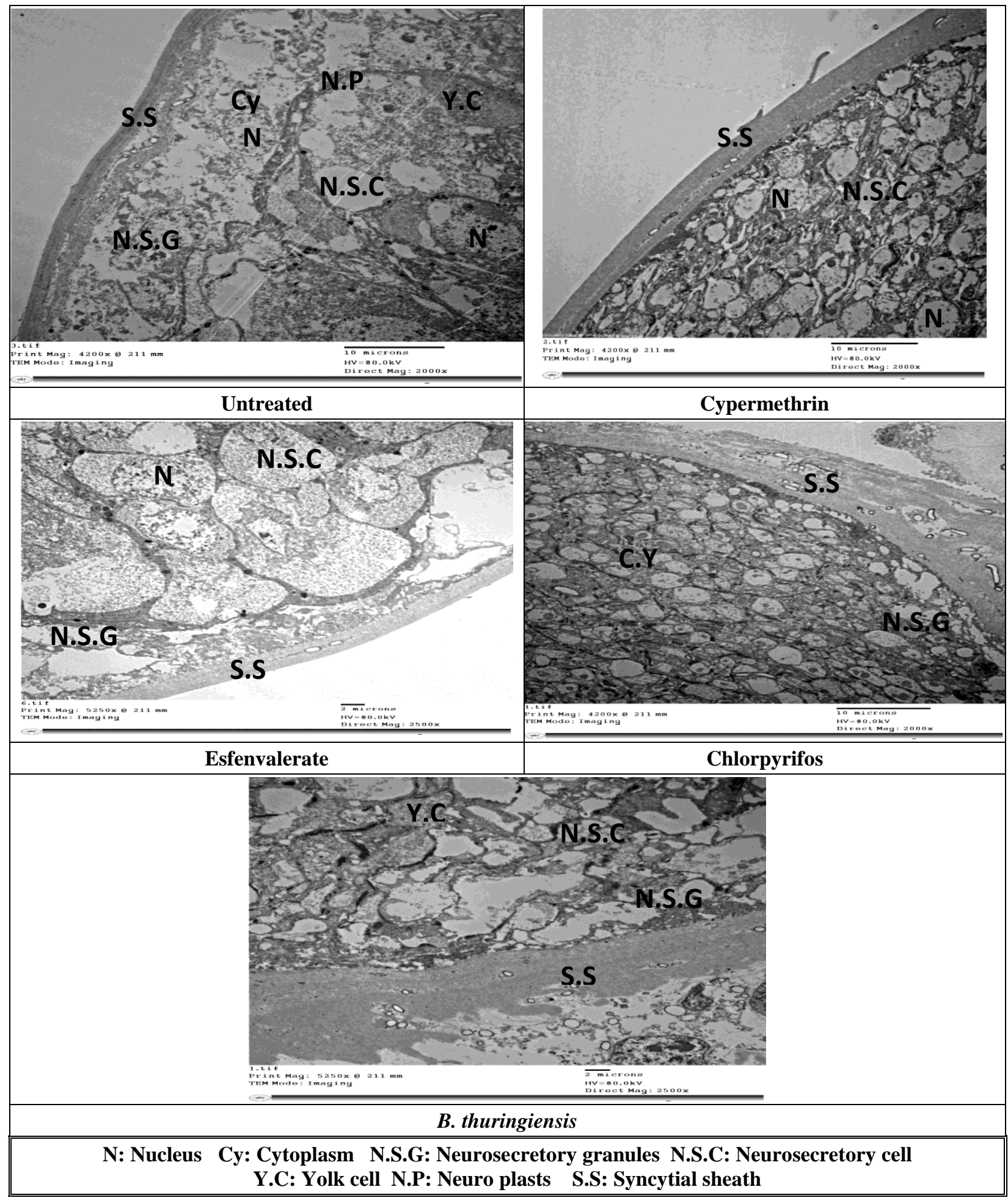

Figure (8): Longitudinal sections by electronic microscope in larval ganglion of $S$. littoralis treated as $4^{\text {th }}$ instars larvae by tested compounds (X 2500).

\section{REFERENCES}

Abd El-Mohsen, S.M.; Abd El-Baki, M. A.; El-Naggar, J. B.and El-Nagar, E.Y. (2013): Efficiency of some insecticides sequence on cotton bollworms and histopathological effects of some biocides on pink bollworm. Egypt. J. Agric. Res., 91 (2): 429448.
Abd-EL Wahed, M. S.; Ahmed, F. M.; Abdel-Aal, A. E. and Abdel-Aziz, M. M. (2011): The effect of certain biocontrol agent on some biological, biochemical and histological aspects of the cotton leaf worm Spodoptera littoralis (Boisd.) (Lepidoptera: Noctuidae). Egypt. J. Agric. Res., 89 (2): 431-444. 
Abul-Nasr, S. and El-Sherif, S. T. (1973): Seasonal fluctuations of the egg masses of the cotton leaf worm, Spodoptera littoralis (Boisd.) in cotton fields. Bulletin de la Société Entomologique d'Egypte, 57: 353-360.

Amer, R.A.; Yacoub, Sh. S. and Salem, M.S. (2015): Histopathological effects of some bio agent compounds exposed to gamma irradiation on the cotton leaf worm, Spodoptera littoralis (Boisd.). J. Plant Prot. And Path., Mansoura Univ., 6(10): 1369-1380.

Bancroft, J.D.; Steven, A. and Turner, D.R. (1990): Theory and practice of histological techniques. $3^{\text {rd }}$ ed. Churchill, Livingstone, Ldinburgh, London, Melbourne and New York.

Bhatti, S.S.; Ahmad, M.; Yousaf, K. and Naeem, M. (2013): Pyrethroids and new chemistry insecticides mixture against Spodoptera litura (Noctuidae: Lepidoptera) under laboratory conditions. Asian J Agri Biol, 1(2):45-50.

Bozzola, J.J., Russell, L.D. (1999): Electron Microscopy, Second Edition. Sudbury, MA: Jones and Bartlett Publishers.

Dulmage,T. H. and Co-operators (1981): Insecticidal activity of isolates of Bacillus thuringiensis and their potential for pest control. In "Microbial Control of Pests and Plant Diseases 1970-1980." (H.D. Burges, ed.). pp. 193-223. Academic Press, London and New York.

El- Sheikh, T. A. (2012): Biological, biochemical and histological effects of spinosad, Bacillus thuringiensis var. kurstaki and cypermethrin on the Cotton leaf worm, Spodoptera littoralis (Boisd.). Egypt. Acad. J. biolog. Sci., 4 (1): 113 124.

El- Sheikh, T.A. ; Ismail, S.A.; El-Kawas, H. M.; ElSayed, S.A. and Tolba, H. I. (2005): Biological and biochemical effects of Serratia marcescens (Eubacteriales:Enterobacteria) as microbial agent and the chitin synthesis inhibitor lufenuron on the cotton leaf worm, $S$. littoralis (Boisd.) (Lepidoptera: Noctuidae). Egypt. J. Agric. Res., 2 (2): 785-797.
El-Defrawi, M. E.; Toppozada, A.; Mansour, N. and Zeid, M. (1964): Toxicological studies on the Egyptian cotton leaf worm, Prodenia litura I. Susceptibility of different larval instars to insecticides. J. Econ. Entomol. 57: 591-593.

El-Metwally, H.E.; Emara, S.,A. and Amer, R.A. (2007): Histopathological effects of certain insecticides on the pink and spiny bollworms. Egypt.J.Agric.Res., 85(2): 523-534.

Finney. D.J. (1971): Probit analysis. $3^{\text {rd }} E d n$. Cambridge University press, Cambridge, UK., p318.

Hamouda, L.S. and Dahi, H.F. (2008): Neurotoxic effect of spinetoram on Spodoptera littoralis (Boisd.) Larvae. Egypt. Acad. J. biolog. Sci., 1 (2) 27 - 36.

Ibrahim, S.A. ;Abdelazim, A.M. and Youssef, S.S. (2014): Physiological and toxicological effects of dible 2X (Bacillus thuringiensis) on the Egyptian cotton leaf worm Spodoptera littoralis (Lepidoptera: Noctuidae). International Journal of Advanced Research, 2 (10): 133-139.

Massoud, A.H.; Derbalah, A.S.; El-Shshtaway, H.; Sleem, F.M. (2014): Efficacy, persistence and removal of chlorpyrifos-methyl after application against cotton leaf worm in soybean. J. Mater. Environ. Sci. 5 (5): 1398-1405.

Osman, H. and Abou-zeid, N. (2015): Bio-Efficiency component of capsicum extract, profenofos and their mixture on some biochemical and histological aspects of Spodoptera littoralis (Boisd.). Australian Journal of Basic and Applied Sciences, 9(20): 70-77.

Osman, H.H. (2014): Comparison of efficiency of some compounds and their biochemical effects against cotton leaf worm, Spodoptera littoralis (Boisd.) in the field. J. Biol. Chem. Research, 31 (1): 260-274.

Sampsont, M. N. and Gooday, G.W. (1998): Involvement of chitinases of Bacillus thuringiensis during pathogenesis in insects. Microbiology, 144 (2): 18 9-219.

Tripathi, P.N. and Arif, M. (2005): Neuroendocrine organs and neurosecretion in Indian tasar silk worm, Antheraea mylitta D. (Lepidoptera: Saturnüdae). Biochem. Cell Arch. 5(1):37-72. 
Nancy N. Hassan et al.

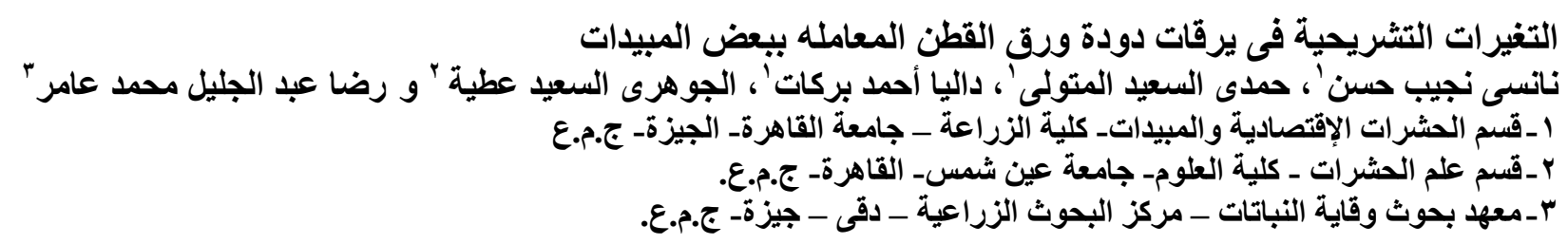

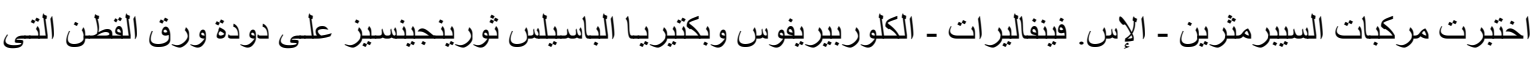

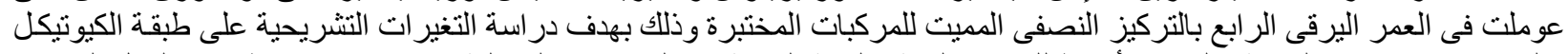

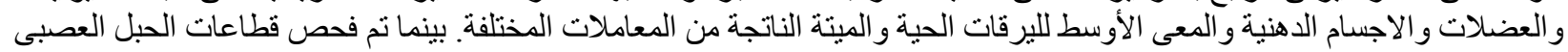

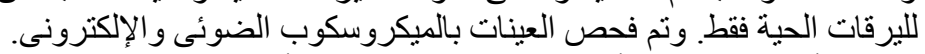

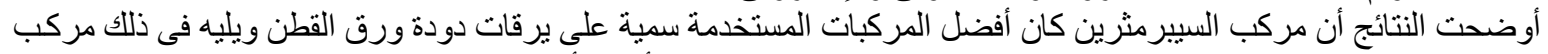

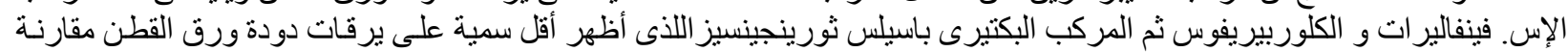
بالمركبات المختبرة السابقة.

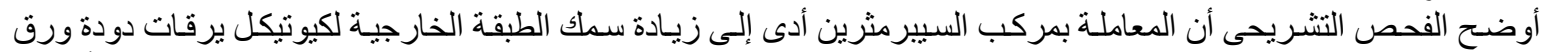

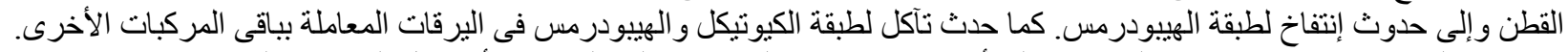

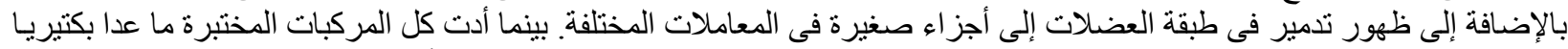

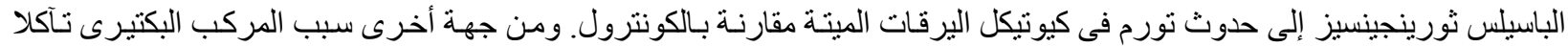

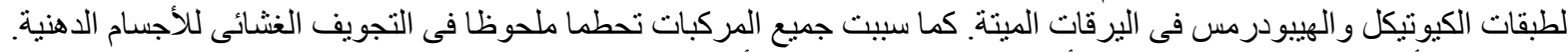

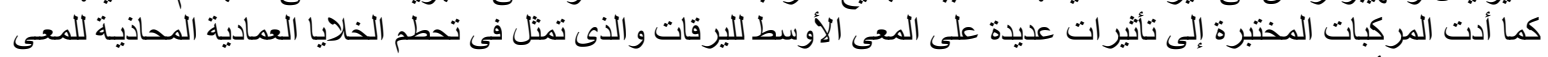

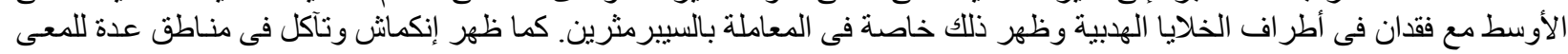

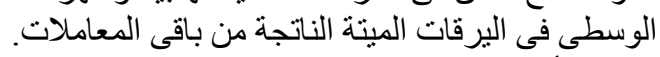

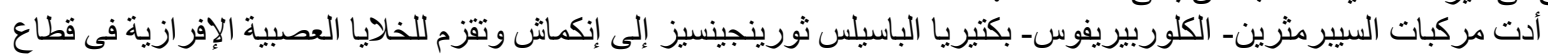

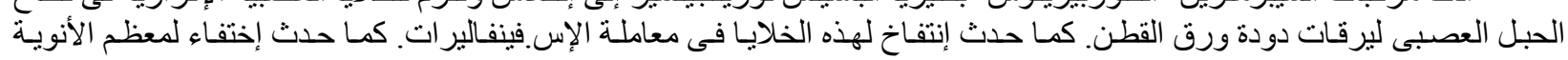
و الخلايا العصبية لليرقات الناتجة من المعاملة بمعظم المركبات المختلفة وذلك مقارنة بالعقدة العصبية غير المعاملة (الكونترول). 